\title{
A Comparative Study on Adoption of Organic and Inorganic Pesticides by the Vegetable Growers in Bishnupur District of Manipur
}

\author{
Darelli Naveen*, Daya Ram, M. Kunjaraj Singh and N. Gopimohan Singh \\ Department of Extension Education, College of Agriculture, Central Agricultural University, \\ Imphal, Manipur, India \\ *Corresponding author
}

\section{A B S T R A C T}

\section{Keywords}

Nambol, Vegetable growers, Adoption, Organic pesticides, Inorganic pesticides

Article Info

\section{Accepted:}

18 March 2021

Available Online:

10 April 2021
Pesticides coupled with other modern inputs undoubtedly have enabled the country to achieve unparalleled increase in agricultural productivity over the last five decades and thus enabled to achieve food security. The term pesticide covers a wide range of compounds including insecticides, fungicides, herbicides, rodenticides, molluscicides, nematicides, plant growth regulators and others. In the present era, the agrochemicals used in agriculture are produced from fossil fuel, and are not renewable and diminishing in availability. Looking to all these aspects, the present study was conducted in Nambol Block of Bishnupur district of Manipur with total respondents of 100 vegetable growers selected from five villages which are selected through simple random sampling procedure during the year 2019-20. An ex-post-facto research design was adopted for this study. The four objectives of the current research were to study the sociopersonal, socio-economic and psychological characteristics of vegetable growers, to measure the extent of adoption of organic and inorganic pesticides by the vegetable growers, to find out the relationship between selected independent variables and dependent variable and to identify the problems faced by the vegetable growers. The data was collected through personal interview method. The statistical tools: mean, frequency, standard deviation, percentage, correlation coefficient, and regression analysis were used for interpretation and analysis of the data collected from the respondents. The data collected from 50 respondents of organic pesticides adopters revealed that the majority $(48.00 \%)$ of the vegetable growers had 'medium' extent of adoption of organic pesticides followed by 'high' $(26.00 \%)$ and 'low' $(26.00 \%)$. whereas data collected from 50 respondents of Inorganic pesticides adopters revealed that the majority (38.00\%) of the vegetable growers had 'high' extent of adoption of Inorganic pesticides followed by 'low' (36.00\%) and 'medium' $(26.00 \%)$. The eight variables i.e., (Education, Farming experience, Farm size, Annual income, Input availability, Training undergone, Mass media exposure and Risk-taking ability) and eight variables i.e., (Age, Farming experience, Annual income, Input availability, Extension contact, Training undergone, Mass media exposure and Market accessibility) were found to be positively and significantly related to the extent of adoption of organic and inorganic pesticides respectively at 0.01 and 0.05 level of probability. The regression analysis revealed that six variables (Education, Farming experience, Farm size, Annual income, Training undergone and Mass media exposure) and four variables (Input availability, Extension contact, Training undergone and Risk-taking ability) contributed significantly to the prediction on extent of adoption of organic and Inorganic pesticides among vegetable growers respectively. A resilient and healthy finding of the study was that all the twelve independent variables jointly contributed $(82.70 \%)$ and $(72.30 \%)$ towards the variations in the extent of adoption of organic and Inorganic pesticides among vegetable growers respectively. The F-values being 14.776 and 8.040 were also found significant at 0.01 level of probability for organic and inorganic pesticides adopting vegetable growers respectively. which indicated the significant effect of the independent variables in predicting the extent of adoption of organic and inorganic pesticides among vegetable growers when all the independent variables were functioning jointly. 


\section{Introduction}

Pesticides coupled with other modern inputs undoubtedly have enabled the country to achieve unparalleled increase in agricultural productivity over the last five decades and thus enabled to achieve food security. However, evidences indicate that in India, pests cause crop loss of more than Rs. 6000 crores annually, of which 46.00 per cent is due to insects and diseases, 33.00 per cent is due to weeds, 10.00 per cent by birds and rodents and the remaining $(11.00 \%)$ is due to other factors.

India is the second largest producer of vegetables in the world (ranks next to china) $\&$ accounts for about 14.00 per cent of world production of vegetables with the productivity of 17.70 tonnes/ha which is quite low compared to other countries. As per the final estimates of 2017-18, horticulture production stood at record $311.7 \mathrm{MT}$, which is 3.70 per cent higher than the previous year and 10.00 per cent higher than the past five years' average production.

In present case of vegetables potato, tomato, onion, cabbage and cauliflower account for around 60.00 per cent of the total vegetable production in the country. Vegetables are typically grown in India in field conditions; the concept is opposed to the cultivation of vegetables in green houses as practised in developed countries for high yields.

The pesticide consumption has not been uniformed in the country, and it varies with the intensity of pests and diseases, cropping pattern and agro-ecological regions with good irrigational facilities and in areas where commercial crops are grown.

Currently, there are 288 pesticides registered for use in India including bio pesticides. The consumption of chemical pesticides in agriculture went up from 2,350 metric tonnes (technical grade) in 1950-51 to 75,033 metric tonnes (MT) in 1990-91, and subsequently declined to 57,000 metric tonnes in 2016-17. The recent statistics on consumption of pesticides (technical grade) for the year 201617 shows that Maharashtra is the leading consumer of pesticides (13,496 MT) followed by Uttar Pradesh (10,142 MT), Punjab (5843 MT), Haryana (4050 MT), and Telangana (3840 MT). The predominant classes of pesticides used (during 2016-17) are insecticides, accounting for 40.00 per cent of total consumption, followed by fungicides $(38.00 \%)$, herbicides $(18.00 \%)$ and others $(4.00 \%)$.

Total consumption of chemical and organic pesticides in vegetables in India is 4699.06 MT in the year 2011-12. Regarding the consumption of chemicals pesticides for different crops, Cereals accounts for 12,155.27 MT followed by Fibres (6,898.49 MT), Pulses $(4,996.14$ MT), and Vegetables (3,773.14 MT). Regarding the consumption of organic pesticides, Pulses accounts for 1,149.44 MT followed by Cereals (1,033.01 MT), Vegetables (925.92 MT), and Oil seeds (831.12 MT).

Regarding the consumption of pesticide for different crops, cotton consumed 55.00 per cent of total pesticides in India while the total area under cotton was only 5.00 per cent. Similarly, in the case of paddy, 17.00 per cent of the pesticide was consumed, while the total area under paddy was 24.00 per cent. In case of fruits and vegetables, the usage was 13.00 per cent of total production and the area was only 3.00 per cent of the total cultivated area. Looking to all these aspects, a research project entitled "A Comparative Study on Adoption of Organic and Inorganic Pesticides by the Vegetable Growers in Bishnupur District of Manipur" was undertaken with following specific objectives: 
To study socio-personal, socio-economic and psychological characteristics of the vegetable growers.

To measure the adoption of organic and inorganic pesticides by the vegetable growers.

To find out the relationship between selected independent variables and dependent variable

\section{Significance of the study}

This analysis on adoption of organic and inorganic pesticides among the respondents will be helpful to provide the base-line for developing measures to increase pesticides use efficiency and safety measures while using of pesticides. The problems encountered will be helpful for the researchers to rectify the problems related to pesticides availability, use and application.

Findings of this investigation give some light on the adoption of organic and inorganic pesticides among the vegetable growers of the Bishnupur district of Manipur and also provides information regarding the sociopersonal, socio-economic and psychological characteristics affecting the adoption of organic and inorganic pesticides by the vegetable growers of Bishnupur district of Manipur. This study also helped in the important problems faced by the vegetable growers.

\section{Materials and Methods}

The present study was conducted in Nambol Block of Bishnupur district of Manipur with total of 100 respondents. An ex-post-facto research design was adopted for this study. The data was collected through personal interview method through a structurally developed interview schedule. The collected data were analysed using appropriate statistical tools and analysis.

\section{Selection of district}

Out of the 16 Districts in Manipur, Bishnupur district was selected purposively for the study because in this district vegetable growing farmers are more.

\section{Selection of block}

Bishnupur district have 3 blocks namely Bishnupur, Moriang, Nambol. Nambol block was selected purposively for study because in this block vegetable growing farmers are more.

\section{Selection of villages}

There are 14 villages in Nambol block, out of those 14 villages, 5 villages (Leimaram mayai leikai, heinoubok, kabowakching, leimapokpam, lourembam) was selected randomly for the study.

\section{Selection of respondents}

In each village 10 growers using organic pesticides and 10 growers using inorganic pesticides was selected randomly. Likewise, a total of 20 respondents was selected from each village.

\section{Results and Discussion}

It is evident from the table-1 that majority $(50.00 \%)$ of the vegetable growers adopting Trichoderma in the adoption of organic pesticides for seed treatment followed by the non-adoption category (28.00\%), Bhejamrutha $(16.00 \%)$ and Mycostop (6.00\%). In adoption of organic pesticides in nursey total $(100.00 \%)$ respondents belonged to non-adoption category. In adoption of organic pesticides for insect management majority $(36.00 \%)$ of the vegetable growers adopting NSKE/Neem oil followed by non-adoption (16.00\%) category, Neemastram $\quad(22.00 \%), \quad$ Brahmastram 
(14.00\%), Agnastram (12.00\%). In adoption of organic pesticides for disease management majority $(56.00 \%)$ of the vegetable growers belonged to non-adoption category followed by adoption of Trichoderma (14.00\%), Neem oil $(10.00 \%)$, Def-guard (10.00\%), Mycostop $(6.00 \%)$ and Panchagavya (4.00\%). In adoption of organic pesticides for storage management total $(100.00 \%)$ vegetable growers belonged non-adoption category.

It is evident from the table- 2 that majority $(50.00 \%)$ of the vegetable growers belonged to the non-adoption category in the adoption of Inorganic pesticides for seed treatment followed by adoption of Carbendazim (20.00\%), Captan (16.00\%) and Thiram $(14.00 \%)$. In adoption of Inorganic pesticides in nursey majority (37.00\%) respondents belonged to non-adoption category followed by adoption of Metalaxyl (10.00\%), Captan $(6.00 \%)$, Mercurous Chloride $(6.00 \%)$ and Benomyl plus $(4.00 \%)$. In adoption of Inorganic pesticides for insect management majority $(42.00 \%)$ of the vegetable growers belonged to non-adoption category followed by adoption of Coragen (22.00\%), Sulphur (wettable powder) (16.00\%), Super Killer $(10.00 \%)$ and Lancer gold (10.00\%). In adoption of Inorganic pesticides for disease management majority $(32.00 \%)$ of the vegetable growers belonged to non-adoption category followed by adoption of Carbendazim (22.00\%), Sixer (20.00\%), Sulphur Dust (12.00\%), Copper oxy chloride (8.00) and Metalaxyl (6.00\%). In adoption of Inorganic pesticides for storage management total $(100.00 \%)$ vegetable growers belonged non-adoption category.

It is revealed from the results presented in table-3 and Fig-1 that when we observe organic pesticides adopting farmers majority $(48.00 \%)$ of the vegetable growers belonged to medium level of adoption category followed by low and high level of adoption category with same $(26.00 \%)$ proportion.

Whereas, in Inorganic pesticides adopting farmers majority $(38.00 \%)$ of the vegetable growers belonged to high level of adoption category followed by the low $(36.00 \%)$ and medium $(26.00 \%)$ category.

The collected data were tabulated and computed to assess the extent of the relationship between socio-personal, socioeconomic and psychological characteristics of the vegetable growers and the extent of adoption of organic pesticides. From the data tabulated in table-4, It is evident that Education, Farming experience, Farm size, Annual income, Input availability, Training undergone, Mass media exposure and Risktaking ability were found to be positively and significantly related to the extent of adoption of organic pesticides among vegetable growers at 0.01 and 0.05 level of probability.

Cost of cultivation were found to be negatively and significantly related to the extent of adoption of organic pesticides among vegetable growers at 0.05 level of probability. Age, Extension contact and Market accessibility were not significantly related with the extent of adoption of organic pesticides among vegetable growers.

Whereas, extent of the relationship between socio-personal, socio-economic and psychological characteristics of the vegetable growers and the extent of adoption of Inorganic pesticides from the table-5, explains that Age, Farming experience, Annual income, Input availability, Extension contact, Training undergone, Mass media exposure and Market accessibility were found to be positively and significantly related to the extent of adoption of Inorganic pesticides among vegetable growers at 0.01 and 0.05 level of probability. 
Table.1 Distribution of vegetable growers based on practice-wise adoption of organic pesticides

\begin{tabular}{|c|c|c|c|c|}
\hline \multirow{3}{*}{$\begin{array}{c}\text { Sl. No. } \\
1\end{array}$} & \multirow{2}{*}{\multicolumn{2}{|c|}{ Adoption of organic pesticides }} & \multirow{3}{*}{$\begin{array}{c}\text { Frequency (f) } \\
14\end{array}$} & \multirow{3}{*}{$\begin{array}{c}\mathrm{n}=50 \\
\text { Percentage }(\%) \\
28.00\end{array}$} \\
\hline & & & & \\
\hline & \multirow{5}{*}{$\begin{array}{c}\text { Adoption of organic } \\
\text { pesticides in Seed treatment }\end{array}$} & Non adoption & & \\
\hline & & Trichoderma & 25 & 50.00 \\
\hline & & Bheejamruth & 8 & 16.00 \\
\hline & & Mycostop & 3 & 6.00 \\
\hline & & Total & 50 & 100.00 \\
\hline \multirow[t]{2}{*}{2} & \multirow{2}{*}{$\begin{array}{l}\text { Adoption of organic } \\
\text { pesticides Nursery }\end{array}$} & Non adoption & 50 & 100.00 \\
\hline & & Total & 50 & 100.00 \\
\hline \multirow[t]{6}{*}{3} & \multirow{6}{*}{$\begin{array}{l}\text { Adoption of organic } \\
\text { pesticides Insect } \\
\text { management }\end{array}$} & Non adoption & 8 & 16.00 \\
\hline & & NSKE/Neem oil & 18 & 36.00 \\
\hline & & Neemastram & 11 & 22.00 \\
\hline & & Brahmastram & 7 & 14.00 \\
\hline & & Agnastram & 6 & 12.00 \\
\hline & & Total & 50 & 100.00 \\
\hline \multirow[t]{7}{*}{4} & \multirow{7}{*}{$\begin{array}{l}\text { Adoption of organic } \\
\text { pesticides Disease } \\
\text { management }\end{array}$} & Non adoption & 28 & 56.00 \\
\hline & & Trichoderma & 7 & 14.00 \\
\hline & & Neem oil & 5 & 10.00 \\
\hline & & Def-guard & 5 & 10.00 \\
\hline & & Mycostop & 3 & 6.00 \\
\hline & & Panchagavya & 2 & 4.00 \\
\hline & & Total & 50 & 100.00 \\
\hline \multirow[t]{2}{*}{5} & \multirow{2}{*}{$\begin{array}{l}\text { Adoption of organic } \\
\text { pesticides Storage } \\
\text { management }\end{array}$} & Non adoption & 50 & 100.00 \\
\hline & & Total & 50 & 100.00 \\
\hline
\end{tabular}

Fig.1 Distribution of vegetable growers based on their extent of adoption of Organic and Inorganic pesticides

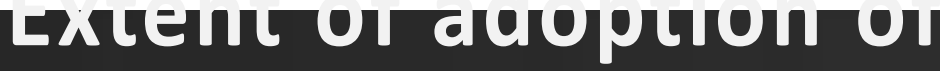 Organic and Inorganic pesticides \\ $13,26 \% 8,36 \% \quad 24,48 \% 23,26 \% \quad 13,26 \% 19,38 \%$
low
medium
high

extent of adoption of organic pesticides by vegetable growers 
Table.2 Distribution of vegetable growers based on practice wise adoption of Inorganic pesticides

\begin{tabular}{|c|c|c|c|c|}
\hline Sl. No. & Category & Particulars & Frequency & Percentage \\
\hline \multirow{5}{*}{1} & \multirow{5}{*}{$\begin{array}{c}\text { adoption of Inorganic } \\
\text { pesticides in Seed } \\
\text { treatment }\end{array}$} & Non adoption & 25 & 50.00 \\
\hline & & Carbendazim & 10 & 20.00 \\
\hline & & Captan & 8 & 16.00 \\
\hline & & Thiram & 7 & 14.00 \\
\hline & & Total & 50 & 100.00 \\
\hline \multirow{6}{*}{2} & \multirow{6}{*}{$\begin{array}{l}\text { adoption of Inorganic } \\
\text { pesticides in Nursery }\end{array}$} & Non adoption & 37 & 74.00 \\
\hline & & Metalaxyl & 5 & 10.00 \\
\hline & & Captan & 3 & 6.00 \\
\hline & & Mercurous chloride & 3 & 6.00 \\
\hline & & Benomyl plus & 2 & 4.00 \\
\hline & & Total & 50 & 100.00 \\
\hline \multirow{6}{*}{3} & \multirow{6}{*}{$\begin{array}{l}\text { adoption of Inorganic } \\
\text { pesticides in Insect } \\
\text { management }\end{array}$} & Non adoption & 21 & 42.00 \\
\hline & & Coragen & 11 & 22.00 \\
\hline & & Sulphur (w.p) & 8 & 16.00 \\
\hline & & Super killer & 5 & 10.00 \\
\hline & & Lancer gold & 5 & 10.00 \\
\hline & & Total & 50 & 100.00 \\
\hline \multirow{7}{*}{4} & \multirow{7}{*}{$\begin{array}{c}\text { adoption of Inorganic } \\
\text { pesticides in Disease } \\
\text { management }\end{array}$} & Non adoption & 16 & 32.00 \\
\hline & & Carbendazim & 11 & 22.00 \\
\hline & & Sixer & 10 & 20.00 \\
\hline & & $\begin{array}{l}\text { Sulphur Dust } \\
\text { (Wetsulf) }\end{array}$ & 6 & 12.00 \\
\hline & & Copper oxy chloride & 4 & 8.00 \\
\hline & & Metalaxyl & 3 & 6.00 \\
\hline & & Total & 50 & 100.00 \\
\hline \multirow{2}{*}{5} & \multirow{2}{*}{$\begin{array}{c}\text { adoption of Inorganic } \\
\text { pesticides in Storage } \\
\text { management }\end{array}$} & Non adoption & 50 & 100.00 \\
\hline & & Total & 50 & 100.00 \\
\hline
\end{tabular}

Table.3 Distribution of respondents based on their extent of adoption of organic and inorganic pesticides

\begin{tabular}{|c|c|c|c|c|c|}
\hline SI. No. & Category & \multicolumn{2}{|c}{$\begin{array}{c}\text { Adoption of Organic } \\
\text { Pesticides }\end{array}$} & $\begin{array}{c}\text { Adoption of Inorganic } \\
\text { Pesticides }\end{array}$ \\
\cline { 3 - 6 } & Frequency & Percentage & Frequency & Percentage \\
\hline $\mathbf{1}$ & $\begin{array}{c}\text { Low level of } \\
\text { adoption }\end{array}$ & 13 & 26.00 & 18 & 36.00 \\
\hline $\mathbf{2}$ & $\begin{array}{c}\text { Medium level of } \\
\text { adoption }\end{array}$ & 24 & 48.00 & 13 & 26.00 \\
\hline $\mathbf{3}$ & $\begin{array}{c}\text { High level of } \\
\text { adoption }\end{array}$ & 13 & 26.00 & 19 & 38.00 \\
\hline & \begin{tabular}{c} 
Total (50+50) \\
\hline
\end{tabular} & 50 & 100.00 & 50 & 100.00 \\
\hline
\end{tabular}


Table.4 Correlation coefficient on the extent of adoption of organic pesticides among vegetable growers with the independent variables

\begin{tabular}{|c|c|c|}
\hline Sl.no. & Independent Variables & $\begin{array}{c}\text { Correlation co-efficient ' } r ' \\
\text { value }\end{array}$ \\
\hline $\mathbf{1 .}$ & Age $\left(\mathrm{X}_{1}\right)$ & $0.066(\mathrm{NS})$ \\
\hline $\mathbf{2 .}$ & Education $\left(\mathrm{X}_{2}\right)$ & $0.420^{* *}$ \\
\hline $\mathbf{3 .}$ & Farming experience $\left(\mathrm{X}_{3}\right)$ & $0.425^{* *}$ \\
\hline $\mathbf{4 .}$ & Farm size $\left(\mathrm{X}_{4}\right)$ & $0.429^{* *}$ \\
\hline $\mathbf{5 .}$ & Annual income $\left(\mathrm{X}_{5}\right)$ & $0.712^{* *}$ \\
\hline $\mathbf{6 .}$ & Input availability $\left(\mathrm{X}_{6}\right)$ & $0.316^{*}$ \\
\hline $\mathbf{7 .}$ & Cost of cultivation $\left(\mathrm{X}_{7}\right)$ & $-0.335^{*}$ \\
\hline $\mathbf{8 .}$ & Extension contact $\left(\mathrm{X}_{8}\right)$ & $0.249(\mathrm{NS})$ \\
\hline $\mathbf{9 .}$ & Training undergone $\left(\mathrm{X}_{9}\right)$ & $0.329^{*}$ \\
\hline $\mathbf{1 0 .}$ & Mass media exposure $\left(\mathrm{X}_{10}\right)$ & $0.399^{* *}$ \\
\hline $\mathbf{1 1 .}$ & Market accessibility $\left(\mathrm{X}_{11}\right)$ & $0.215(\mathrm{NS})$ \\
\hline $\mathbf{1 2 .}$ & Risk taking ability $\left(\mathrm{X}_{12}\right)$ & $0.312^{*}$ \\
\hline
\end{tabular}

*Significant at 0.05 level of probability

**Significant at 0.01 level of probability

NS: Non-Significant

Table.5 Correlation coefficient on the extent of adoption of Inorganic pesticides among vegetable growers with the independent variables

\begin{tabular}{|c|c|c|}
\hline Sl.no. & Independent Variables & $\begin{array}{c}\text { Correlation co-efficient ' } r \\
\text { value }\end{array}$ \\
\hline $\mathbf{1 .}$ & Age $\left(\mathrm{X}_{1}\right)$ & $0.352^{*}$ \\
\hline $\mathbf{2 .}$ & Education $\left(\mathrm{X}_{2}\right)$ & $-0.289^{*}$ \\
\hline $\mathbf{3 .}$ & Farming experience $\left(\mathrm{X}_{3}\right)$ & $0.357^{*}$ \\
\hline $\mathbf{4 .}$ & Farm size $\left(\mathrm{X}_{4}\right)$ & $0.211(\mathrm{NS})$ \\
\hline $\mathbf{5 .}$ & Annual income $\left(\mathrm{X}_{5}\right)$ & $0.469^{* *}$ \\
\hline $\mathbf{6 .}$ & Input availability $\left(\mathrm{X}_{6}\right)$ & $0.414^{* *}$ \\
\hline $\mathbf{7 .}$ & Cost of cultivation $\left(\mathrm{X}_{7}\right)$ & $-0.142(\mathrm{NS})$ \\
\hline $\mathbf{8 .}$ & Extension contact $\left(\mathrm{X}_{8}\right)$ & $0.438^{* *}$ \\
\hline $\mathbf{9 .}$ & Training undergone $\left(\mathrm{X}_{9}\right)$ & $0.327^{*}$ \\
\hline $\mathbf{1 0 .}$ & Mass media exposure $\left(\mathrm{X}_{10}\right)$ & $0.404^{* *}$ \\
\hline $\mathbf{1 1}$. & Market accessibility $\left(\mathrm{X}_{11}\right)$ & $0.357^{*}$ \\
\hline $\mathbf{1 2 .}$ & Risk taking ability $\left(\mathrm{X}_{12}\right)$ & $-0.489^{* *}$ \\
\hline
\end{tabular}

*Significant at 0.05 level of probability

**Significant at 0.01 level of probability

NS: Non-Significant 
Table.6 Regression coefficient on the extent of adoption of organic pesticides among vegetable growers with selected independent variables

\begin{tabular}{|c|c|c|c|c|c|}
\hline Sl.no. & Independent variables & Beta & B & $\begin{array}{c}\text { Standard } \\
\text { error } \\
\text { (S.E.) }\end{array}$ & t-value of b \\
\hline $\mathbf{1}$ & Age & -0.013 & 0.000 & 0.005 & -0.164 \\
\hline $\mathbf{2}$ & Education & 0.244 & 0.095 & 0.036 & $2.671^{*}$ \\
\hline $\mathbf{3}$ & Farming experience & 0.224 & 0.016 & 0.006 & $2.747^{* *}$ \\
\hline $\mathbf{4}$ & Farm size & 0.317 & 0.109 & 0.030 & $3.650^{* *}$ \\
\hline $\mathbf{5}$ & Annual income & 0.419 & 0.000 & 0.000 & $4.543^{* *}$ \\
\hline $\mathbf{6}$ & Input availability & 0.130 & 0.071 & 0.052 & 1.370 \\
\hline $\mathbf{7}$ & Cost of cultivation & -0.051 & -0.000 & 0.000 & -0.551 \\
\hline $\mathbf{8}$ & Extension contact & 0.000 & 0.000 & 0.022 & 0.004 \\
\hline $\mathbf{9}$ & Training undergone & 0.189 & 0.095 & 0.044 & $2.177^{*}$ \\
\hline $\mathbf{1 0}$ & Mass media exposure & 0.271 & 0.030 & 0.009 & $3.177^{* *}$ \\
\hline $\mathbf{1 1}$ & Market accessibility & -0.090 & -0.056 & 0.051 & -1.094 \\
\hline $\mathbf{1 2}$ & Risk taking ability & -0.041 & -0.012 & 0.026 & -0.471 \\
\hline *Significant at 0.05 level of probability & & & $\mathrm{R}^{2}=0.827$ & \\
\hline **Significant at 0.01 level of probability & & $\mathrm{F}=14.776$ & \\
\hline
\end{tabular}

Table.7 Regression coefficient on the extent of adoption of Inorganic pesticides among vegetable growers with selected independent variables

\begin{tabular}{|c|c|c|c|c|c|}
\hline Sl.no. & Independent variables & Beta & B & $\begin{array}{c}\text { Standard } \\
\text { error } \\
\text { (S.E.) }\end{array}$ & t-value of b \\
\hline $\mathbf{1}$ & Age & -0.038 & -0.003 & 0.009 & -0.346 \\
\hline $\mathbf{2}$ & Education & -0.089 & -0.039 & 0.047 & -0.832 \\
\hline $\mathbf{3}$ & Farming experience & 0.033 & 0.003 & 0.009 & 0.337 \\
\hline $\mathbf{4}$ & Farm size & 0.142 & 0.065 & 0.047 & 1.371 \\
\hline $\mathbf{5}$ & Annual income & 0.085 & 0.000 & 0.000 & 0.660 \\
\hline $\mathbf{6}$ & Input availability & 0.270 & 0.209 & 0.085 & $2.471^{*}$ \\
\hline $\mathbf{7}$ & Cost of cultivation & 0.035 & 0.000 & 0.000 & 0.329 \\
\hline $\mathbf{8}$ & Extension contact & 0.289 & 0.146 & 0.051 & $2.871^{* *}$ \\
\hline $\mathbf{9}$ & Training undergone & 0.228 & 0.148 & 0.064 & $2.298^{*}$ \\
\hline $\mathbf{1 0}$ & Mass media exposure & 0.214 & 0.033 & 0.017 & 1.901 \\
\hline $\mathbf{1 1}$ & Market accessibility & 0.196 & 0.122 & 0.064 & 1.902 \\
\hline $\mathbf{1 2}$ & Risk taking ability & -0.337 & -0.225 & 0.071 & $-3.160^{* *}$ \\
\hline *Significant at 0.05 level of probability & & & $\mathrm{R}^{2}=0.723$ & \\
**Significant at 0.01 level of probability & & \\
\hline
\end{tabular}


Education and Risk-taking ability were found to be negatively and significantly related to the extent of adoption of organic pesticides among vegetable growers at 0.01 and 0.05 level of probability. Farm size and Cost of cultivation were not significantly related with the extent of adoption of Inorganic pesticides among vegetable growers.

The findings from the regression analysis to assess the contribution of all the twelve selected independent variables with the extent of adoption of organic pesticides among vegetable growers was presented in table-6. In the determination of the regression coefficient, it was found that out of all the twelve independent variables only six variables. i.e.,Education, Farming experience, Farm size, Annual income, Training undergone and Mass media exposure contributed positively and significantly to the prediction on extent of adoption of organic pesticides among vegetable growers and they may be entitled as good predictors of extent of adoption of organic pesticides. A resilient and healthy finding of the study was that all the twelve independent variables jointly contributed $(82.70 \%)$ towards the variations in the extent of adoption of organic pesticides among vegetable growers. The F-value being 14.776 was also found significant at 0.01 level of probability.

The findings from the regression analysis to assess the contribution of all the twelve selected independent variables with the extent of adoption of Inorganic pesticides among vegetable growers was presented in table-7. In the determination of the regression coefficient, it was found that out of all the twelve independent variables only four variables. i.e.,Input availability, Extension contact and Training undergone contributed positively and significantly whereas, Risk taking ability contributed negatively and significantly to the prediction on extent of adoption of Inorganic pesticides among vegetable growers and they may be entitled as good predictors of extent of adoption of Inorganic pesticides. A resilient and healthy finding of the study was that all the twelve independent variables jointly contributed $(72.30 \%)$ towards the variations in the extent of adoption of Inorganic pesticides among vegetable growers. The F-value being 8.040 was also found significant at 0.01 level of probability. Finally, it can be concluded that from both organic and inorganic pesticides adopting vegetable grower's majority of them belong to the medium extent of adoption.

Education, Farming experience, Farm size, Annual income, Input availability and Risktaking ability were the important factors which have contributed to the overall extent of adoption of organic and inorganic pesticides among vegetable growers in the Bishnupur district of Manipur. Adoption of organic pesticides in vegetables and others crops helps in maintaining health at the same time soil fertility also, so in Manipur, farmers are using organic pesticides till date. Whereas adoption of inorganic pesticides helps in controlling large proportion of pests and diseases. Effective adoption of both organic and inorganic pesticides even though a complex process with proper planning, finance, and efficient human resources we can make it happen for sustainable agriculture. To keep pace with the developing other sectors all over the country, agriculture needs to re-define and re-evaluate their roles more consistently and systematically.

\section{Acknowledgements}

I express my sincere thanks to my Major Advisor and Chairman of the Advisory Committee, Dr. Daya Ram, Assistant Professor, Department of Extension Education, College of Agriculture, Central Agricultural University, Imphal.I am thankful 
to the members of my advisory committee, Dr. M. Kunjaraj Singh, Professor \& Ex-Head of Department of Extension Education, College of Agriculture, Central Agricultural University, Imphal.Dr. Y. Chakrabarty Singh, Professor \& Head, Department of Agricultural Economics and Dr. N. Gopimohan Singh, Associate Professor, Department of Agricultural Statistics, College of Agriculture, Central Agricultural University, Imphal, for their guidance and help rendered throughout this study.

\section{References}

Anonymous. (2012). State/Selected Crop-wise Consumption of Chemical and Biopesticides in India. Ministry of
Agriculture, Government of India. https://www.indiastat.com

Anonymous. (2017). State-wise Consumption of Pesticides (Technical Grade), in India. Ministry of Statistics and Programme Implementation, Government of India. https://www.indiastat.com

Dikshit, A.K. (2008). Pesticide Protecting Crops and Environment: The Journey has Just Began. Corp Care, 34(3): 3741.

Rajendran, P. (2003). Plant Insecticidal Proteins and their Potential for Developing Transgenics Resistant to Insect Pests. Indian J. Biotechnol. 2: 110-120.

\section{How to cite this article:}

Darelli Naveen, Daya Ram, M. Kunjaraj Singh and Gopimohan Singh, N. 2021. A Comparative Study on Adoption of Organic and Inorganic Pesticides by the Vegetable Growers in Bishnupur District of Manipur. Int.J.Curr.Microbiol.App.Sci. 10(04): 800-809. doi: https://doi.org/10.20546/ijcmas.2021.1004.083 